\title{
Leg feathers in an Early Cretaceous bird
}

\section{This feature supports the idea that the evolution of flight involved a four-winged stage.}

H ere we describe a fossil of an enantiornithine bird from the Early Cretaceous period in China that has substantial plumage feathers attached to its upper leg (tibiotarsus). The discovery could be important in view of the relative length and aerodynamic features of these leg feathers compared with those of the small 'fourwinged' gliding dinosaur Microraptor ${ }^{1,2}$ and of the earliest known bird, Archaeoptery $x^{3,4}$. They may be remnants of earlier long, aerodynamic leg feathers, in keeping with the hypothesis that birds went through a fourwinged stage during the evolution of flight ${ }^{1}$.

Some modern birds rely on structural features of their legs for assistance during flight - for example, the kittiwake (Rissa tridactyla) will spread out its webbed feet to provide an air brake, and the lappet-faced vulture (Torgos tracheliotus) stretches its legs and feet to their full extent in order to achieve a steep descent onto a kill ${ }^{5,6}$.

Unlike modern birds, but like the basal dromaeosaur Microraptor, the legs of the new enantiornithine bird possess relatively long pennaceous feathers that are about half the length of the tibiotarsus; they are curved and situated mainly along the outer side of this bone (Fig. 1). Although the preservation of these feathers shows little evidence of asymmetry, their distinctive curvature may indicate a residual aerodynamic function ${ }^{3,5,7}$.

In the four-winged dinosaur Microraptor gui, the extremely long leg feathers show unambiguous asymmetric vanes and curvature $^{1}$ that clearly had some aerodynamic function. The presence of leg feathers in Archaeopteryx has, after some controversy, been reconfirmed, although it is still not known whether they retained some aerodynamic function ${ }^{4}$. The leg feathers in the new enantiornithine are longer than those in Archaeopteryx when compared with the length of the tibiotarsus, and they appear to be more aerodynamic than the leg feathers in Archaeopteryx.

The tail feathers (rectrices) of modern birds contribute to lift during flight ${ }^{3,5,6,8}$. Compared with what we know about the wing feathers (remiges) and skeleton, however, little is known about the role of the tail feathers of basalbirds in the evolution of early avian flight ${ }^{8}$, even though many Mesozoic bird fossils have been discovered ${ }^{9-11}$. The tail feathers of the new bird are short compared with those of modern birds, as is the case for many other Mesozoic birds, such as Confuciusornis, Changchengornis, Protopteryx and Yixianornis, although many of these specimens have a pair of long central tail feath$\operatorname{ers}^{11-13}$. It is possible that the short tail feathers

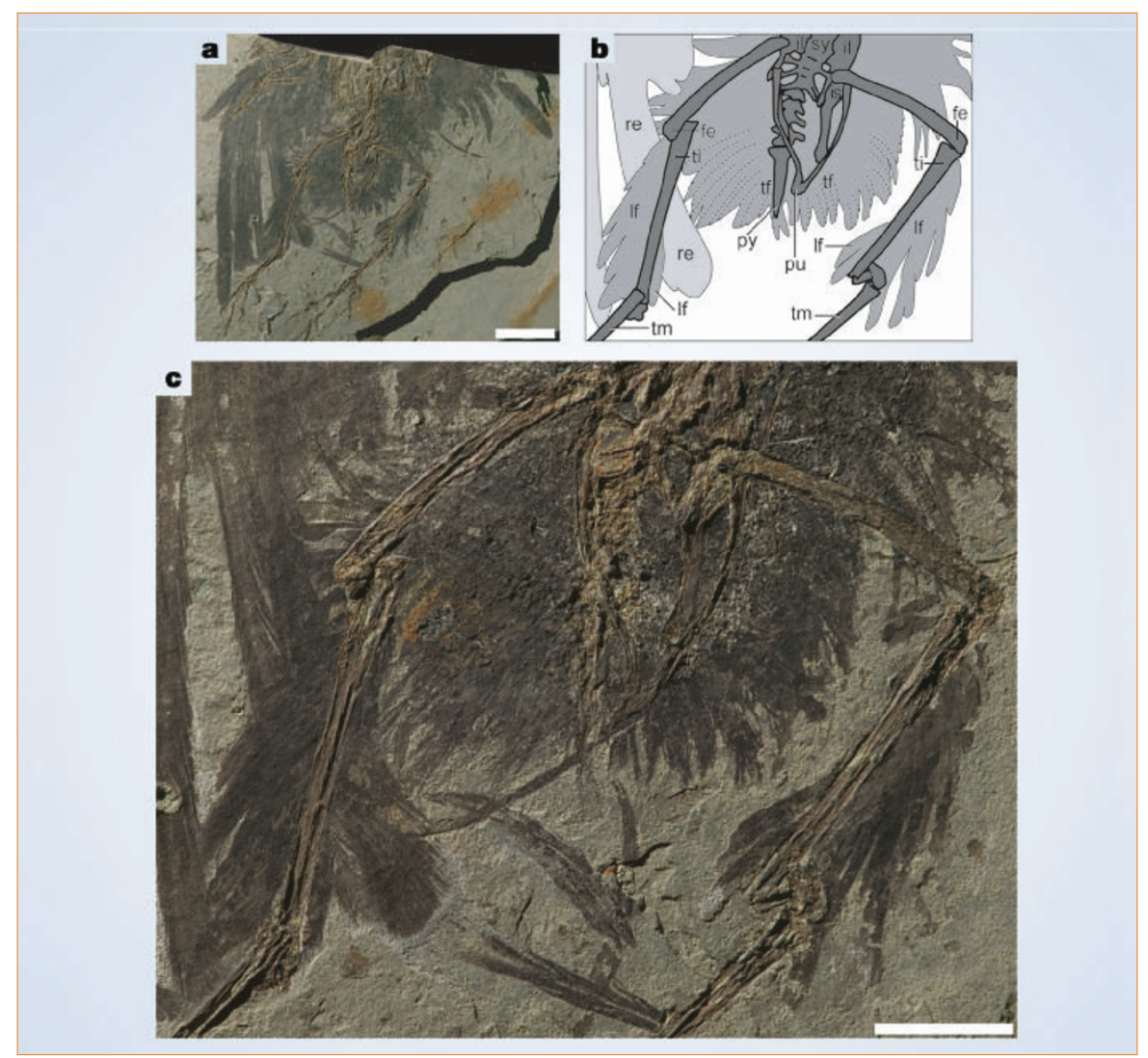

Figure 1 A fossil bird from the Early Cretaceous Yixian Formation at Jingangshan locality in Yixian, Liaoning Province, northeast China (IVPP Collection V 13939). Its caudally notched sternum, increased length of metacarpal III compared with II, and its reduced metatarsal IV indicate that it was an enantiornithine bird. a, Photograph of the specimen in a single slab, showing the association of the preserved skeletal elements, almost all of which are articulated, with feathers. b, c, Drawing (b) and close-up (c) of the specimen, which has long, aerodynamic feathers attached to its legs (If) and weak, narrow and relatively short tail feathers (tf). Abbreviations in $\mathbf{b}$ : fe, femur; il, ilium; is, ischium; pu, pubis; py, pygostyle; re, remiges; sy, synsacrum; ti, tibiotarsus; tm, tarsometatarsus. Scale bars: a, $2 \mathrm{~cm} ; \mathbf{b}, 1 \mathrm{~cm}$.

could be the result of moulting, although more evidence would be needed to corroborate this. If, however, the short tail feathers of the new bird and of other basal taxa are correctly recognized, then they might represent a primitive feature.

The flight ability of these early birds has been generally acknowledged ${ }^{3,9-11}$, although it was probably not as strong as it is in modern birds. The weak aerodynamic features of the leg feathers of the new bird could have helped the poorly developed tail in manoeuvring during flight, rather as the modern razorbill (Alca torda) uses its large webbed feet to supplement its small tail during slow flight ${ }^{6}$.

Phylogenetically, enantiornithines are a more advanced group of birds than Archaeopteryx. The hindlimb wing of Microraptor was probably a primitive form that was later reduced in most birds. The leg feathers of Archaeopteryx and the new enantiornithine fossil may represent vestigial examples of a feature that made an important contribution to flight in early birds.

\section{Fucheng Zhang, Zhonghe Zhou}

Institute of Vertebrate Paleontology and

Paleoanthropology, Chinese Academy of Sciences,

PO Box 643, Beijing 100044, China

e-mail: fuchengzhang@yeah.net

1. Xu, X. et al. Nature 421, 335-340 (2003).

2. Prum, R. O. Nature 421, 323-324 (2003)

3. Feduccia, A. The Origin and Evolution of Birds (Yale Univ. Press, New Haven \& London, 1999).

4. Christiansen, P. \& Bonde, N. Comptes Rendus Palevol. 3, 99-118 (2004).

5. Norberg, U. M. Vertebrate Flight: Mechanics, Physiology, Morphology, Ecology and Evolution (Springer, Berlin, 1990). 6. Pennycuick, C. Animal Flight (Arnold, London, 1972).

7. Norberg, R. Å. in The Beginnings of Birds (eds Hecht, M. K. et al.) 303-318 (Freunde Jura-Museum, Eichstätt, 1985). 8. Gatesy, S. M. in New Perspectives on the Origin and Early Evolution of Birds (eds Gauthier, J. \& Gall, L. F.) 237-254 (Peabody Mus. Nat. Hist., Yale Univ., New Haven, 2001). 9. Padian, K. \& Chiappe, L. M. Biol. Rev. 73, 1-42 (1998).

10. Witmer, L. M. in Mesozoic Birds: Above the Heads of Dinosaurs (eds Chiappe, L. M. \& Witmer, L. M.) 3-30 (California Univ. Press, Berkeley, 2002).

11.Zhou, Z., Barrett, P. M. \& Hilton, J. Nature 421, 807-814 (2003). 12. Chiappe, L. M., Ji, S., Ji, Q. \& Norell, M. A. Bull. Am. Mus. Nat. Hist. 242, 3-89 (1999).

13. Chang, M., Chen, P., Wang, Y.-Q. \& Wang, Y. (eds) The Jehol Biota (Shanghai Sci. Technol. Publ., Shanghai, 2003).

Competing financial interests: declared none. 